\title{
Temporal regulation of mRNAs for select bone morphogenetic proteins (BMP), BMP receptors and their associated SMAD proteins during bovine early embryonic development: effects of exogenous BMP2 on embryo developmental progression
}

Kyung-Bon Lee ${ }^{1,2,4}$, Joseph K Folger ${ }^{1,2}$, Sandeep K Rajput ${ }^{1,2}$ and George W Smith ${ }^{1,2,3^{*}}$

\begin{abstract}
Background: We previously demonstrated embryotrophic actions of maternal (oocyte-derived) follistatin during bovine early embryogenesis. Classical actions of follistatin are attributed to inhibition of activity of growth factors including activins and bone morphogenetic proteins (BMP). However, temporal changes in BMP mRNA in early bovine embryos and the effects of exogenous BMP on embryo developmental progression are not understood. The objectives of present studies were to characterize mRNA abundance for select BMP, BMP receptors and BMP receptor associated SMADs during bovine oocyte maturation and early embryogenesis and determine effects of addition of exogenous BMP protein on early development.

Methods: Relative abundance of mRNA for BMP2, BMP3, BMP7, BMP10, SMAD1, SMAD5, ALK3, ALK6, ALK2, BMPR2, $A C V R 2 A$ and $A C V R 2 B$ was determined by RT-qPCR analysis of germinal vesicle (GV) and in vitro matured metaphase II (MII) oocytes and in vitro produced embryos collected at pronuclear, 2-cell (C), 4C, 8C, 16C, morula and blastocyst stages. Effects of addition of recombinant human BMP2 (0, 1, 10 and $100 \mathrm{ng} / \mathrm{ml})$ during initial $72 \mathrm{~h}$ of embryo culture on early cleavage (within $30 \mathrm{~h}$ post insemination), total cleavage, development to 8C-16C and blastocyst stages and blastocyst mRNA abundance for markers of inner cell mass (NANOG) and trophectoderm (CDX2) were also determined.

Results: Abundance of mRNA for BMP2, BMP10, SMAD1, SMAD5, ALK3, ALK2, BMPR2 and ACVR2B was elevated in MII oocytes and/or pronuclear stage embryos (relative to GV) and remained elevated through the $8 C-16 C$ stages, whereas BMP3, BMP7 and ALK2 mRNAs were transiently elevated. Culture of embryos to the $8 C$ stage in the presence of a-amanitin resulted in increased abundance for all of above transcripts examined relative to untreated $8 \mathrm{C}$ embryos. Effects of addition of exogenous BMP2 on early cleavage rates and rates of development to 8C-16C and blastocyst stages were not observed, but BMP2 treatment increased blastocyst mRNA for CDX2 and NANOG. (Continued on next page)
\end{abstract}

\footnotetext{
* Correspondence: smithge7@msu.edu

${ }^{1}$ Department of Laboratory of Mammalian Reproductive Biology and

Genomics, Michigan State University, East Lansing, Ml 48824, USA

${ }^{2}$ Department of Animal Science, Michigan State University, East Lansing,

MI 48824, USA

Full list of author information is available at the end of the article
}

C Biomed Central (c) 2014 Lee et al.; licensee BioMed Central Ltd. This is an Open Access article distributed under the terms of the Creative Commons Attribution License (http://creativecommons.org/licenses/by/4.0), which permits unrestricted use, distribution, and reproduction in any medium, provided the original work is properly credited. The Creative Commons Public Domain Dedication waiver (http://creativecommons.org/publicdomain/zero/1.0/) applies to the data made available in this article, unless otherwise stated. 
(Continued from previous page)

Conclusions: Abundance of maternally derived mRNAs for above BMP system components are dynamically regulated during oocyte maturation and early embryogenesis. Exogenous BMP2 treatment does not influence progression to various developmental endpoints, but impacts characteristics of resulting blastocysts. Results support a potential role for BMPs in bovine early embryogenesis.

Keywords: Ovary, Bovine, Oocyte, Embryo, Blastocyst, BMP, BMP receptor, SMAD

\section{Background}

Oocyte developmental competence was defined by Sirard et al. [1] as the capacity of the oocyte to resume meiosis, cleave after fertilization, help promote embryonic development and implantation, and bring a pregnancy to term in good health [1]. Our previous studies support a positive functional role for maternal (oocyte-derived) follistatin in bovine oocyte competence. Follistatin mRNA is positively associated with developmental competence in two distinct bovine models of egg quality $[2,3]$. Furthermore, follistatin supplementation during the first $72 \mathrm{~h}$ of bovine embryo culture (until embryonic genome activation) enhanced proportion of embryos that cleaved early and proportion of embryos developing to the blastocyst stage in a dose dependent fashion [3]. Follistatin treatment also increased total blastocyst cell numbers specifically through an increase in trophectoderm (TE) cells, with no effect on numbers of inner cell mass (ICM) cells and increased blastocyst mRNA for the TE specific transcription factor CDX2 [3]. We also observed similar effects of follistatin treatment on early cleavage and rates of development to blastocyst stage for rhesus monkey embryos [4], demonstrating potential translational relevance of results from the bovine model system. However, the mechanisms responsible for stimulatory effects of follistatin on multiple indices of bovine early embryonic development to date still remain elusive.

Follistatin was initially classified as a high affinity binding protein inhibiting activin action [5]. However, stimulatory effects of exogenous activin treatment on early cleavage and blastocyst rates for bovine embryos were also observed suggesting a potential alternative mechanism of follistatin action [3]. Follistatin can also bind and regulate activity of multiple additional TGF $\beta$ superfamily members including BMPs [6-8]. A prominent role for BMPs in regulation of patterning of early embryos has been described [9]. Furthermore, BMPs have been implicated in regulation of trophoblast differentiation in human embryonic stem cells [10]. However, less is known about their role during preimplantation embryonic development, particularly in farm species.

In this study, we investigated temporal changes in mRNA abundance for multiple BMP, BMP receptors and their associated SMADs in bovine oocytes and embryos and the source of such transcripts (maternal versus embryonic) in bovine embryos coincident with embryonic genome activation. We also determined the effect of exogenous BMP2 on multiple endpoints relevant to bovine early embryonic developmental progression. Results demonstrate dynamic regulation of maternal mRNAs for BMP system components during bovine early embryonic development and effects of exogenous BMP2 treatment on indices of cell lineage determination in bovine blastocysts. Results also suggest embryotropic actions of follistatin on bovine early embryogenesis are likely not mediated by antagonism of BMP2 signaling.

\section{Methods \\ Oocyte collection, in vitro maturation, in vitro fertilization and embryo culture}

Bovine oocytes used for all described experiments were obtained from ovaries harvested at a local abattoir. Aspiration and in vitro maturation of oocytes, in vitro fertilization and culture of embryos was performed as previously described [3]. Cumulus-oocyte complexes (aspirated from 2-7 $\mathrm{mm}$ visible follicles) with $>4$ compact cumulus cell layers and homogeneous cytoplasm were matured in TCM 199 [supplemented with $0.2 \mathrm{mM}$ sodium pyruvate, $5 \mathrm{mg} / \mathrm{ml}$ gentamicin sulfate, $6.5 \mathrm{mM}$ L-glutamine, $156 \mathrm{nM}$ bovine LH (Sioux Biochemical, Sioux Center, Iowa), $15.6 \mathrm{nM}$ bovine FSH (Sioux Biochemical), $3.67 \mathrm{nM} \mathrm{17 \beta -estradiol} \mathrm{and} \mathrm{10 \%} \mathrm{v/v}$ defined FBS (Hyclone, Logan, UT)] for $24 \mathrm{~h}$ at $38.5^{\circ} \mathrm{C}$, $5 \% \mathrm{CO}_{2}$ in air with maximum humidity. For in vitro fertilization, matured oocytes were washed and coincubated with sperm for $20 \mathrm{~h}$ in fertilization medium (114 mM NaCl, $25 \mathrm{mM} \mathrm{NaHCO}, 3.2 \mathrm{mM} \mathrm{KCl}, 0.34 \mathrm{mM}$ $\mathrm{NaH}_{2} \mathrm{PO}_{4}, 0.183 \mathrm{mM}$ penicillin-G, $16.6 \mathrm{mM}$ sodium lactate, $0.5 \mathrm{mM} \mathrm{MgCl}_{2} \cdot 6 \mathrm{H}_{2} \mathrm{O}, 2.7 \mathrm{mM} \mathrm{CaCl} 2 \cdot 2 \mathrm{H}_{2} \mathrm{O}, 0.2 \mathrm{mM}$ sodium pyruvate, $6 \mathrm{mg} / \mathrm{ml} \mathrm{BSA}$ and $1.5 \mathrm{U}$ of heparin) at $38.5^{\circ} \mathrm{C}, 5 \% \mathrm{CO}_{2}$ in air with maximum humidity. After cumulus cell removal, presumptive zygotes were washed and cultured in potassium simplex optimization medium (KSOM; EMD Millipore, Billerica MA) supplemented with $0.3 \%$ BSA for $72 \mathrm{~h}$. Embryos were then washed and cultured in fresh KSOM medium supplemented with 0.3\% BSA and 10\% FBS until day 7. 
Temporal changes in BMP system mRNA abundance in bovine oocytes and early embryos

Germinal vesicle (GV) and metaphase (MII) stage (oocytes), pronuclear (PN), 2-cell (C), 4C, 8C, 16C, morula and blastocyst stage embryos $(n=4$ pools of 10 each), were collected as we described previously $[3,11]$. For GV and MII stage oocyte RNA samples, cumulus cells were completely removed by hyaluronidase $(0.1 \%)$ digestion and repeated pipetting and denuded oocytes in groups of 10 each were snap frozen in $100 \mu$ lysis solution (RNAqueous Micro Kit, Ambion Inc, Austin, TX) and stored at $-80^{\circ} \mathrm{C}$ until RNA isolation. Embryo samples were also processed as described above in groups of 10 per sample per stage with PN embryos harvested at $20 \mathrm{~h}$ post insemination (hpi), 2C embryos collected 33 hpi, $4 \mathrm{C}$ embryos $44 \mathrm{hpi}$, 8C embryos $52 \mathrm{hpi}$, 16C embryos 72 hpi, and morulas and blastocysts at 5 and $7 \mathrm{~d}$ post insemination respectively. 250 femtograms of polyadenylated GFP RNA were added to each sample prior to RNA extraction. After finishing RNA isolation and cDNA synthesis, cDNA was diluted 1:5 and mRNA quantification for $B M P 2, B M P 3, B M P 7, B M P 10, A L K 2$, $A L K 3, A L K 6, B M P R 2, A C V R 2 A, A C V R 2 B, S M A D 1$ and $S M A D 5$ mRNAs was performed in duplicate for each sample by qPCR using our procedures reported previously [11]. Relative expression levels were calculated using the $\triangle \triangle C T$ method with RPS18 as the housekeeping gene [12], RPS18 mRNA abundance is very stable across MII through $16 \mathrm{C}$ stages and then is increased in later stages coincident with increase in cell numbers (Additional file 1: Figure S1). Abundance of exogenous control (GFP) RNA was also measured to account for variation in RNA recovery and cDNA synthesis across samples and exogenous GFP mRNA abundance was similar $(P>0.2)$ across samples. Primer sequences and fragment sizes for all transcripts measured are included in Table 1 and PCR efficiencies for all primer sets were between 90 and 103\%.

\section{Effect of transcriptional inhibition on BMP system mRNA abundance}

To determine the effects of inhibition of transcription on mRNA abundance in in vitro derived embryos, presumptive zygotes were cultured in serum free KSOM with $0.3 \%$ BSA with or without the addition of $50 \mu \mathrm{g} / \mathrm{ml}$ $\alpha$-amanitin (Sigma, St. Louis, MO). The $8 \mathrm{C}$ embryos were then collected at $52 \mathrm{~h}$ post insemination $(\mathrm{n}=4$ pools of 10 embryos per group) and placed in lysis buffer and snap frozen and stored as above until RNA isolation. Half the RNA was subjected to reverse transcription using oligo(dT) primers as described above for use in quantification of polyadenylated transcripts for genes of interest. The remaining RNA was transcribed using random hexamers for quantification of adenylated and deadenylated (total) transcripts for genes of interest. The cDNA produced was subjected to qPCR for the BMP system components as described above. Data were normalized relative to abundance of endogenous control (RPS18).

\section{Effect of BMP2 supplementation on bovine embryo developmental progression}

To examine the effect of BMP2 supplementation on early cleavage rate (assessed $30 \mathrm{hpi}$ ), rate of development to $8 \mathrm{C}-16 \mathrm{C}$ stage (assessed $72 \mathrm{hpi}$ ), blastocyst rate (assessed $7 \mathrm{~d}$ post insemination) and the abundance of mRNA for the TE marker (CDX2) and ICM marker (NANOG) in resulting blastocysts, presumptive zygotes were cultured in KSOM medium supplemented with $0.3 \%$ BSA containing $0,1,10$ or $100 \mathrm{ng} / \mathrm{ml} \mathrm{BMP} 2$ (30 presumptive zygotes per group, 4 replicates). The $8 \mathrm{C}$ 16C stage embryos were then separated $72 \mathrm{~h}$ post fertilization and cultured in fresh KSOM medium (minus exogenous BMP2) supplemented with 0.3\% BSA and $10 \%$ FBS until $d 7$. Blastocysts were harvested at $\mathrm{d} 7$ post fertilization $(n=4$ pools of 5 blastocysts each per treatment) and lysed and frozen as above until RNA isolation and RT-qPCR analysis as described above.

\section{Statistical analysis}

All data were analyzed using one way ANOVA in SAS followed by Fishers Protected Least Significant Difference Test to determine differences between means. For embryo culture experiments, \% data were arc-sin transformed prior to analysis. Data are presented as mean \pm SEM.

\section{Results and discussion}

Temporal regulation of BMP mRNA abundance during oocyte maturation and early embryogenesis

Transcriptome analysis of human oocytes indicates that multiple key components of the TGF $\beta$ superfamily signaling pathway are potentially active [13] and previous studies support a functional role for TGF $\beta$ superfamily members during bovine oocyte maturation and early embryogenesis $[3,14,15]$. Over 20 members of the BMP subfamily have been described [16], and expression of BMP in the bovine ovary has been extensively studied [17-19]. Abundance of specific mRNA transcripts during oocyte maturation and early embryonic development is under complex regulation and influenced by post transcriptional and transcriptional mechanisms in a stage specific fashion [20]. Results of present studies revealed unique temporal changes in mRNA abundance for above BMP examined during oocyte maturation and early embryogenesis (Figure 1). Relative abundance of mRNA for $B M P 2$ (Figure 1A) and BMP10 (Figure 1B) was increased in MII oocytes relative to the GV stage $(\mathrm{P}<0.05)$, but 
Table 1 Sequence of primers for real time RT-PCR for TGF $\beta$ superfamily members and receptors, CDX2 and NANOG

\begin{tabular}{|c|c|c|c|}
\hline Gene & Genbank accession number & Primer sequence & Size (bp) \\
\hline \multirow[t]{2}{*}{$B M P 2$} & BC134682 & F: 5'-AAGGCCCTTGCTTGTCACTTT-3' & 72 \\
\hline & & R: 5'-TGCTTGCCGCTTITCTCTTC-3' & \\
\hline \multirow[t]{2}{*}{ BMP3 } & XM_587912 & F: 5'-ATCTGTGGCTGAGCTGCTTGT-3' & 62 \\
\hline & & R: 5'-GGAAGGGCTGCCTGAGTCT-3' & \\
\hline \multirow[t]{2}{*}{$B M P 7$} & XM_612246 & F: 5'-TGCCACTAGCTCTTCCTGGAA-3' & 65 \\
\hline & & R: 5'-TGAGAGACCCAGGATCCAGAA-3' & \\
\hline \multirow[t]{2}{*}{ BMP10 } & XM_583418 & F: 5'-CGCCCACGAGCAATTCC-3' & 66 \\
\hline & & R: 5'-TCCCCAGGTCCGTTGGA-3' & \\
\hline \multirow[t]{2}{*}{ SMAD1 } & BC116117 & F: 5'-CACCATGAACTGAAACCATTGG-3' & 68 \\
\hline & & R: 5'-GATGCACACCTCCTTCTGCTT-3' & \\
\hline \multirow[t]{2}{*}{ SMAD5 } & DV821574 & F: 5'-GCAACGTTTCCTGATTCTTTCC-3' & 74 \\
\hline & & R: 5'-GGCGGGTAGGGACTATTTGG-3' & \\
\hline \multirow[t]{2}{*}{ ALK3 } & NM_001076800 & F: 5'-TCAGCGAACTATTGCCAAACAG-3' & 75 \\
\hline & & R: 5'-CCCATCCACACTTCTCCGTATC-3' & \\
\hline \multirow[t]{2}{*}{ ALK6 } & NM_001105328 & F: 5'-CCCACCCCTCGTCCAAAG-3' & 63 \\
\hline & & R: 5'-GACCGAGTCTTCTGGACAATGG-3' & \\
\hline \multirow[t]{2}{*}{$A L K 2$} & BC133311 & F: 5'-TTGGCCTCATCATTTTGTCTGT-3' & 70 \\
\hline & & R: 5'-CGGAGAGCAACTCCCAATAGG-3' & \\
\hline \multirow[t]{2}{*}{ ACVR2A } & NM_174227 & F: $5^{\prime}$ - CCACAAACCCGCCATATCTC - -3' & 185 \\
\hline & & R: 5'- TAGCACCCTCTAACACCTCTG -3' & \\
\hline \multirow[t]{2}{*}{$A C V R 2 B$} & NM_174495 & F: 5'-GGAGCCATCAACTTCCAGAG-3' & 121 \\
\hline & & R: 5'-GCATGTACTCATCCACAGGTC-3' & \\
\hline \multirow[t]{2}{*}{ BMPR2 } & XM_002685492 & F: 5'-AACACCACTCAGTCCACCTC-3' & 120 \\
\hline & & R: 5'-GTCAGCATCCTATATCCAAAGCA-3' & \\
\hline \multirow[t]{2}{*}{ NANOG } & NM_001025344 & F: 5'-AAAGTTACGTGTCCTTGCAAACG-3' & 73 \\
\hline & & R: 5'-GAGGAGGGAAGAGGAGAGACAGT-3' & \\
\hline \multirow[t]{2}{*}{$\operatorname{CDX} 2$} & AM293662 & F: 5'-FCGTCTGGAGCTGGAGAAGGA-3' & 70 \\
\hline & & R: 5'-CGGCCAGTTCGGCTTTC-3' & \\
\hline
\end{tabular}

BMP3 (Figure 1C) and BMP7 (Figure 1D) mRNA abundance did not change during meiotic maturation. For $B M P 2$ and $B M P 10$, mRNA abundance remained elevated in early embryos after fertilization until declining by the $16 \mathrm{C}$ stage $(\mathrm{P}<0.05)$ and remained low in morula and blastocyst stage embryos (Figure $1 \mathrm{~A}$ and $\mathrm{B}$ ). In contrast, relative mRNA abundance for $B M P 3$ was transiently elevated $(>15$ fold) in $2 \mathrm{C}$ embryos $(\mathrm{P}<0.05)$ and did not differ at other time points examined (Figure $1 C$ ). BMP7 mRNA (Figure 1D) was also transiently elevated at the $2 \mathrm{C}$ stage and was lowest at $16 \mathrm{C}$, morula and blastocyst stages $(\mathrm{P}<0.05)$. Results demonstrate dynamic, ligand specific temporal regulation of mRNA abundance for $B M P 2, B M P 3, B M P 7$ and $B M P 10$ during bovine oocyte maturation and early embryogenesis.

The BMPs bind to multiple TGF $\beta$ superfamily receptors [16]. Expression of BMP receptors in bovine ovarian sections and or isolated oocytes has been reported previously [19], but temporal regulation of mRNA abundance for BMP receptors during oocyte maturation and early embryogenesis is not understood. In the current study, temporal changes in abundance of mRNA in bovine oocytes and early embryos for the prominent Type I $(A L K 3, A L K 6, A L K 2)$ and Type II receptors (BMPR2, $A C V R 2 A, A C V R 2 B)$ that bind BMPs was examined (Figure 2). Abundance of mRNA for $A L K 3$ (Figure 2) was increased in MII oocytes (relative to GV stage), further increased, albeit transiently at the $2 \mathrm{C}$ stage, decreased in $4 \mathrm{C}$ and $8 \mathrm{C}$ embryos and further decreased in $16 \mathrm{C}$, morula and blastocyst stage embryos $(\mathrm{P}<0.05)$. In contrast, ALK6 mRNA (Figure 2B) is elevated at the PN stage, further increased, albeit transiently at the $2 \mathrm{C}$ stage and decreased at $16 \mathrm{C}$, morula and blastocyst stages $(\mathrm{P}<0.05)$. ALK2 mRNA (Figure $2 \mathrm{C}$ ) is transiently elevated in MII oocytes relative to oocytes collected at the GV stage, and reduced even further in embryos 

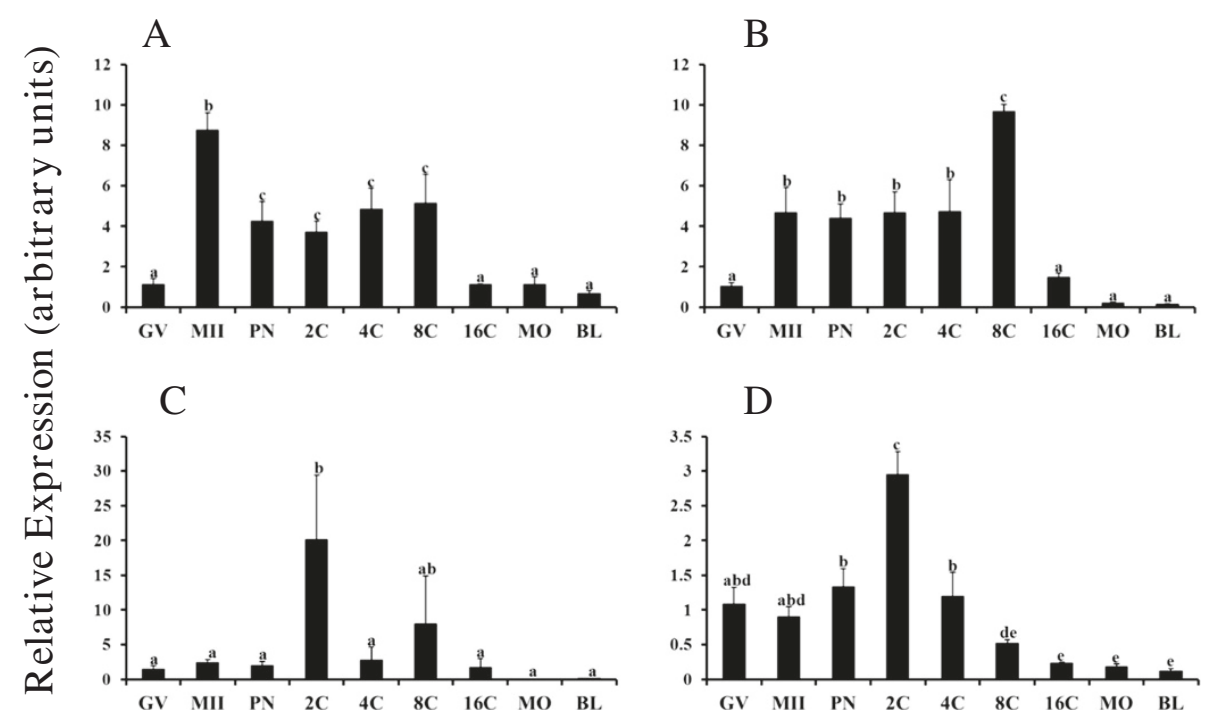

Figure 1 Temporal changes in BMP2 (A), BMP10 (B), BMP3 (C) and BMP7 (D) mRNA abundance during oocyte maturation and early embryogenesis in vitro. Quantitative real time RT-PCR analysis was performed on samples of germinal vesicle (GV) and metaphase II (MII) stage oocytes and in vitro derived embryos collected at the pronuclear (PN), 2-cell (2C), 4-cell (4C), 8-cell (8C), 16-cell (16C), morula (MO) and blastocyst (BL) stages ( $n=4$ pools of 10 oocytes/embryos per pool). Data were normalized relative to abundance of endogenous control (RPS18) and are shown as mean \pm SEM. Values with different superscripts across timepoints denote significant differences $(P<0.05)$.

collected at $4 \mathrm{C}$ stage and beyond $(\mathrm{P}<0.05)$. For the type II receptors, BMPR2 (Figure 2D) is increased in MII oocytes relative to GV stage, further increased post fertilization through the $4 \mathrm{C}$ stage and subsequently declines through $16 \mathrm{C}$ stage $(\mathrm{P}<0.05)$. While mRNA for $A C V R 2 B$ (Figure 2E) but not $A C V R 2 A$ (Figure $2 \mathrm{~F}$ ) was increased in MII oocytes relative to GV stage, mRNA for both $A C V R 2 B$ and $A C V R 2 A$ was elevated at PN stage and remained elevated through the $16 \mathrm{C}$ stage, and was further reduced at morula and blastocyst stages $(\mathrm{P}<0.05$; Figure $2 \mathrm{E}$ and $\mathrm{F})$. Observed temporal regulation of type I and Type II BMP receptor mRNAs supports a potential intrinsic role for BMPs in meiotic maturation and early embryogenesis.

Signal transduction by members of the TGF $\beta$ superfamily is mediated primarily by the SMAD pathways, with BMP signal transduction linked to SMAD1, SMAD5 and SMAD8 [16]. Thus changes in mRNA for BMP receptor associated SMADs during oocyte maturation and early embryogenesis were also investigated (Figure 3). Messenger RNA for SMAD8 was undetectable in bovine oocytes and early embryos. Messenger RNA for SMAD1 (Figure 3A) and SMAD5 (Figure 3B) were increased in MII oocytes relative to GV stage $(\mathrm{P}<$ 0.05). For SMAD1, mRNA remained elevated after fertilization until the $4 \mathrm{C}$ stage and was further decreased in $16 \mathrm{C}$, morula and blastocyst stage embryos $(\mathrm{P}<0.05$; Figure 3A). For SMAD5, mRNA was further increased after fertilization at $\mathrm{PN}, 2 \mathrm{C}$ and $4 \mathrm{C}$ stages and lowest at $16 \mathrm{C}$, morula and blastocyst stages $(\mathrm{P}<0.05$; Figure $3 \mathrm{~B})$.
Effect of embryo culture in the presence of the transcriptional inhibitor a-amanitin on BMP, BMP receptor and SMAD1 and SMAD5 mRNA abundance

Messenger RNA transcript adenylation and deadenylation are prominent mechanisms of regulation of mRNA abundance during oocyte maturation and early development until initiation of embryonic genome activation $[20,21]$. Given abundance of above BMP, BMP type I receptor and SMAD transcripts was elevated in early embryos prior to or through the $8 \mathrm{C}$ stage, studies were done to determine the source (maternal versus embryonic) of BMP2, BMP3, BMP7, BMP10, SMAD1, SMAD5, $A L K 2, A L K 3$ and $A L K 6$, transcripts detected in early bovine embryos. When presumptive zygotes were treated with $50 \mu \mathrm{g} / \mathrm{ml}$ of the RNA polymerase II inhibitor $\alpha$ amanitin for $72 \mathrm{~h}$, relative abundance of mRNA for all BMP system components examined was increased at the $8 \mathrm{C}$ stage compared to control embryos (Table 2). Results suggest that such transcripts present in early embryos at $8 \mathrm{C}$ stage are maternal in origin and that post transcriptional regulation of mRNA abundance for such genes may in fact be transcription dependent. Furthermore elevated transcript abundance was observed when reverse transcription of mRNA was conducted using oligo dT primers and not when random hexamers were utilized (Table 2), suggesting that transcript deadenylation may help contribute to the stage specific decrease in transcript abundance for BMP, BMP receptors and their receptor associated SMAD in the current studies. Since removal of the poly-A tail inhibits translation and is a 


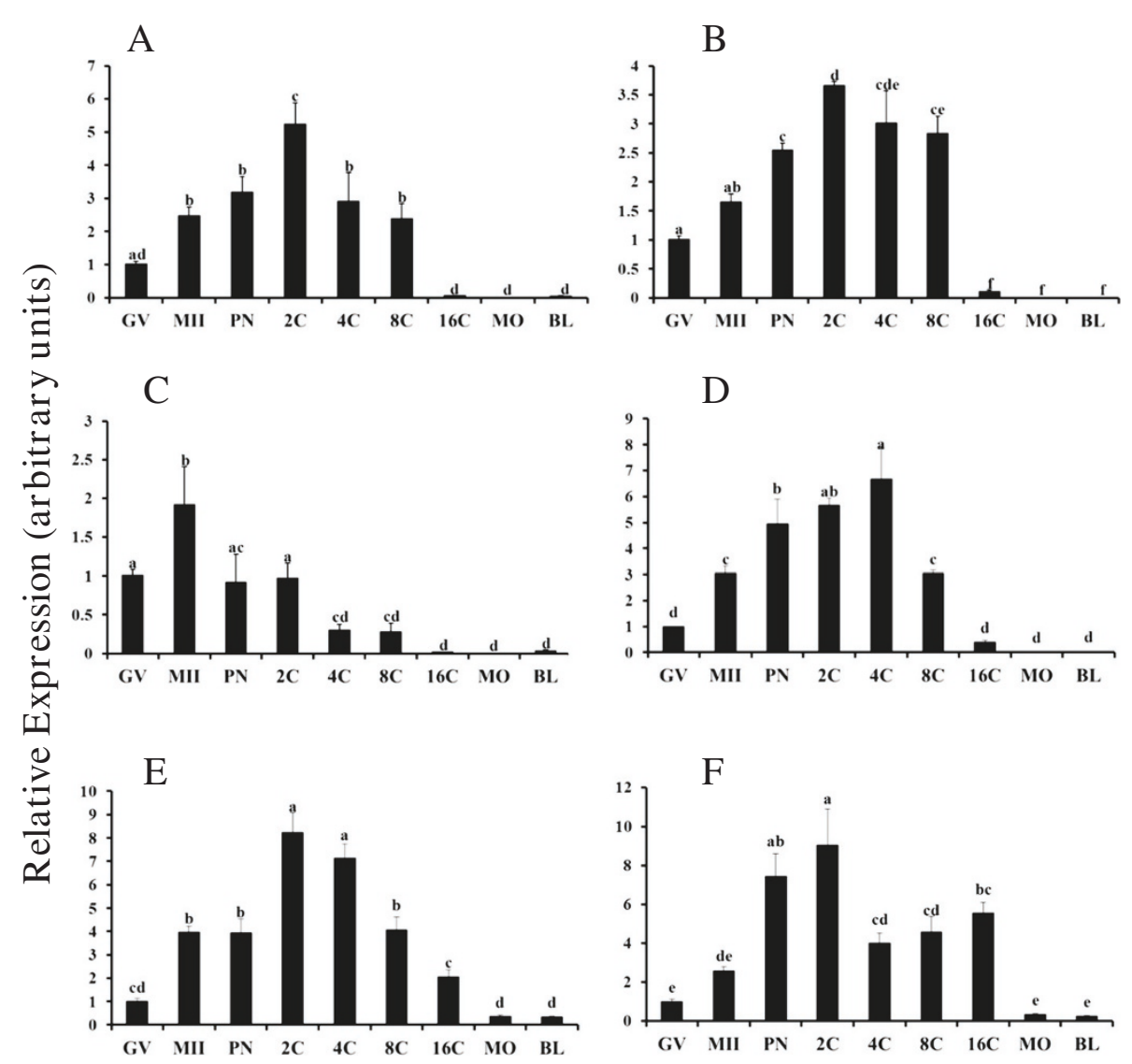

Figure 2 Temporal changes in ALK3 (A), ALK6 (B), ALK2 (C) BMPR2 (D), ACVR2B (E) and ACVR2A (F) mRNA abundance during oocyte maturation and early embryogenesis in vitro. Quantitative real time RT-PCR analysis was performed on samples of germinal vesicle (GV) and metaphase II (MII) stage oocytes and in vitro derived embryos collected at the pronuclear (PN), 2-cell (2C), 4-cell (4C), 8-cell (8C), 16-cell (16C), morula (MO) and blastocyst (BL) stages ( $n=4$ pools of 10 oocytes/embryos per pool). Data were normalized relative to abundance of endogenous control (RPS18) and are shown as mean \pm SEM. Values with different superscripts across time points denote significant differences $(P<0.05)$.

starting point for RNA degradation [22], results suggests that down regulation of above transcripts may be important during stages of embryo development after embryonic genome activation.

\section{Effect of BMP 2 supplementation on embryo development and trophectoderm and inner cell mass marker mRNA abundance in resulting blastocysts}

Previous studies demonstrated a positive association of oocyte follistatin expression with developmental competence [2] and potent embryotrophic actions of follistatin during early embryogenesis including enhanced proportion of embryos cleaving early, increased numbers of embryos developing to the blastocyst stage, and elevated mRNA for the TE cell marker CDX2 in resulting blastocysts [3]. Classical actions of follistatin are commonly attributed to high affinity binding and inhibition of activity of the TGF $\beta$ superfamily member activin [5]. However, previous studies showed stimulatory effects of activin treatment on rates of early cleavage and blastocyst development, suggesting that actions of follistatin on bovine embryos are likely nonclassical [3]. However, follistatin can also bind at a lower affinity and inhibit activity of BMPs [7,17]. The current studies demonstrated dynamic temporal changes in maternal mRNA for several BMP, type I and II BMP receptors and their receptor associated SMADs in bovine embryos prior to genome activation. Therefore to further elucidate the potential role of BMPs in bovine early embryogenesis, effects of BMP2 supplementation during first $72 \mathrm{~h}$ of in vitro embryo culture (through $8 \mathrm{C}-16 \mathrm{C}$ stage) on above developmental endpoints were investigated. The addition of 1,10 or $100 \mathrm{ng} / \mathrm{ml}$ of recombinant human BMP2 did not alter percentage of early cleaving embryos, total cleavage rates, percent embryos developing to $8 \mathrm{C}-16 \mathrm{C}$ stage or blastocyst rate (Figure 4A-D). However supplementation with $100 \mathrm{ng} / \mathrm{ml}$ of BMP2 increased mRNA for the TE marker $C D X 2$ and the ICM marker NANOG relative to embryos cultured without BMP2 (Figure 4E-F). Thus, while BMP2 supplementation did not impact efficiency 
A

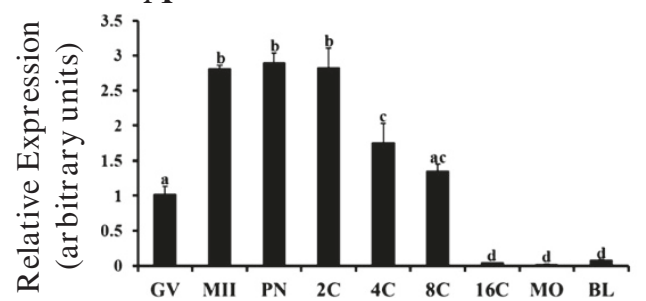

B

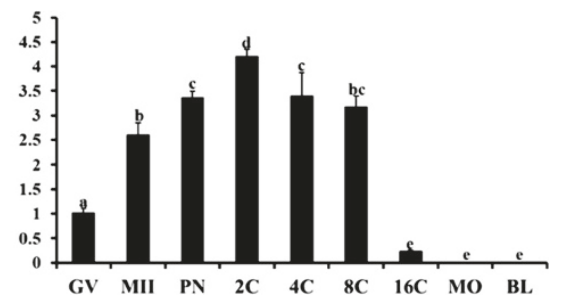

Figure 3 Temporal changes in SMAD1 (A) and SMAD5 (B) mRNA abundance during oocyte maturation and early embryogenesis in vitro. Quantitative real time RT-PCR analysis was performed on samples of germinal vesicle (GV) and metaphase II (MII) stage oocytes and in vitro derived embryos collected at the pronuclear (PN), 2-cell (2C), 4-cell (4C), 8-cell (8C), 16-cell (16C), morula (MO) and blastocyst (BL) stages $(\mathrm{n}=4$ pools of 10 oocytes/embryos per pool). Data were normalized relative to abundance of endogenous control (RPS18) and are shown as mean \pm SEM. Values with different superscripts across time points denote significant differences $(P<0.05)$.

of bovine in vitro embryonic development as measured by numbers of embryos reaching a transferable (blastocyst stage), BMP2 treatment did however impact characteristics of resulting blastocysts as measured by abundance of mRNA for CDX2 and NANOG. These results are in contrast to results obtained following treatment with exogenous follistatin [3] whereby stimulatory effects on CDX2 mRNA, but not NANOG mRNA were observed and suggesting biological actions of follistatin on blastocyst cell allocation are manifest specifically on the TE lineage.

A growing body of evidence suggests that oocyte secreted factors can enhance oocyte developmental competence and embryo developmental progression $[14,15,23]$. Our previous studies support a role for endogenous, oocyte-derived follistatin in promoting bovine embryo developmental progression and cell allocation to the TE lineage [3]. Results were obtained with follistatin treatment during initial stages of embryo culture (d 1-3) up to embryonic genome activation. To our knowledge, effects of exogenous BMP2 treatment during culture of bovine embryos have not been previously reported. Addition of BMP2 or BMP4 during in vitro maturation did not impact rates of meiotic maturation and cumulus expansion or rates of embryonic development to blastocyst stage following in vitro fertilization [19]. However, evidence supports a role for oocyte-derived GDF9 and BMP15 in promoting oocyte developmental competence as addition of these growth factors exogenously during in vitro maturation can enhance rates of development to the blastocyst stage and blastocyst cell allocation to TE $[14,15]$. Thus, levels of endogenous BMP2 available during in vitro maturation and embryo culture may not be limiting to embryo developmental capacity in vitro as reflected by rates of development to the blastocyst stage. However, the current studies do demonstrate that bovine embryos can respond to BMP2 stimulation during initial $3 \mathrm{~d}$ of culture in vitro with an increase in blastocyst mRNA for NANOG and CDX2 measured $4 \mathrm{~d}$ later and demonstrate effects of BMP2 treatment on indices of cell allocation mediated well after treatment administration. The mechanisms responsible for increased blastocyst NANOG and CDX2 mRNA in response to BMP2 stimulation are not known. However, BMP4 mediated induction of CDX2 mRNA expression [24] and promoter activity [25] have been described in other cell lines and

Table 2 Effects of a-Amanitin treatment on mRNA abundance in bovine $8 \mathrm{C}$ embryos

\begin{tabular}{lcccr}
\hline Gene & \multicolumn{2}{c}{ RT with oligo dT } & \multicolumn{2}{c}{ RT with random hexamers } \\
\cline { 2 - 4 } & Control & $\mathbf{a}$-Amanitin treated & Control & a-Amanitin treated \\
\hline SMAD1 & $1.15 \pm 0.27^{\mathrm{a}}$ & $9.08 \pm 1.19^{\mathrm{b}}$ & $1.03 \pm 0.16$ & $1.77 \pm 0.17$ \\
SMAD5 & $1.17 \pm 0.35^{\mathrm{a}}$ & $3.33 \pm 1.27^{\mathrm{b}}$ & $1.02 \pm 0.12$ & $1.45 \pm 0.17$ \\
BMP2 & $1.10 \pm 0.27^{\mathrm{a}}$ & $2.19 \pm 0.76^{\mathrm{b}}$ & $1.25 \pm 0.49$ & $1.30 \pm 0.21$ \\
BMP3 & $1.02 \pm 0.11^{\mathrm{a}}$ & $3.85 \pm 0.60^{\mathrm{b}}$ & $1.15 \pm 0.36$ & $3.26 \pm 0.88$ \\
BMP7 & $1.02 \pm 0.12^{\mathrm{a}}$ & $3.82 \pm 0.66^{\mathrm{b}}$ & $1.17 \pm 0.40$ & $2.96 \pm 1.31$ \\
BMP10 & $1.04 \pm 0.19^{\mathrm{a}}$ & $9.41 \pm 0.75^{\mathrm{b}}$ & $1.07 \pm 0.23$ & $1.59 \pm 0.31$ \\
ALK3 & $1.23 \pm 0.37^{\mathrm{a}}$ & $5.43 \pm 0.71^{\mathrm{b}}$ & $1.06 \pm 0.22$ & $1.42 \pm 0.31$ \\
ALK6 & $1.12 \pm 0.25^{\mathrm{a}}$ & $5.73 \pm 1.34^{\mathrm{b}}$ & $1.05 \pm 0.20$ & $1.38 \pm 0.16$ \\
ALK2 & $1.27 \pm 0.50^{\mathrm{a}}$ & $1.02 \pm 0.13$ & $0.86 \pm 0.09$ \\
\hline
\end{tabular}

Note. Different letters ( $a$ and $b)$ represent significantly different value $(\mathrm{P} \leq 0.05)$. 

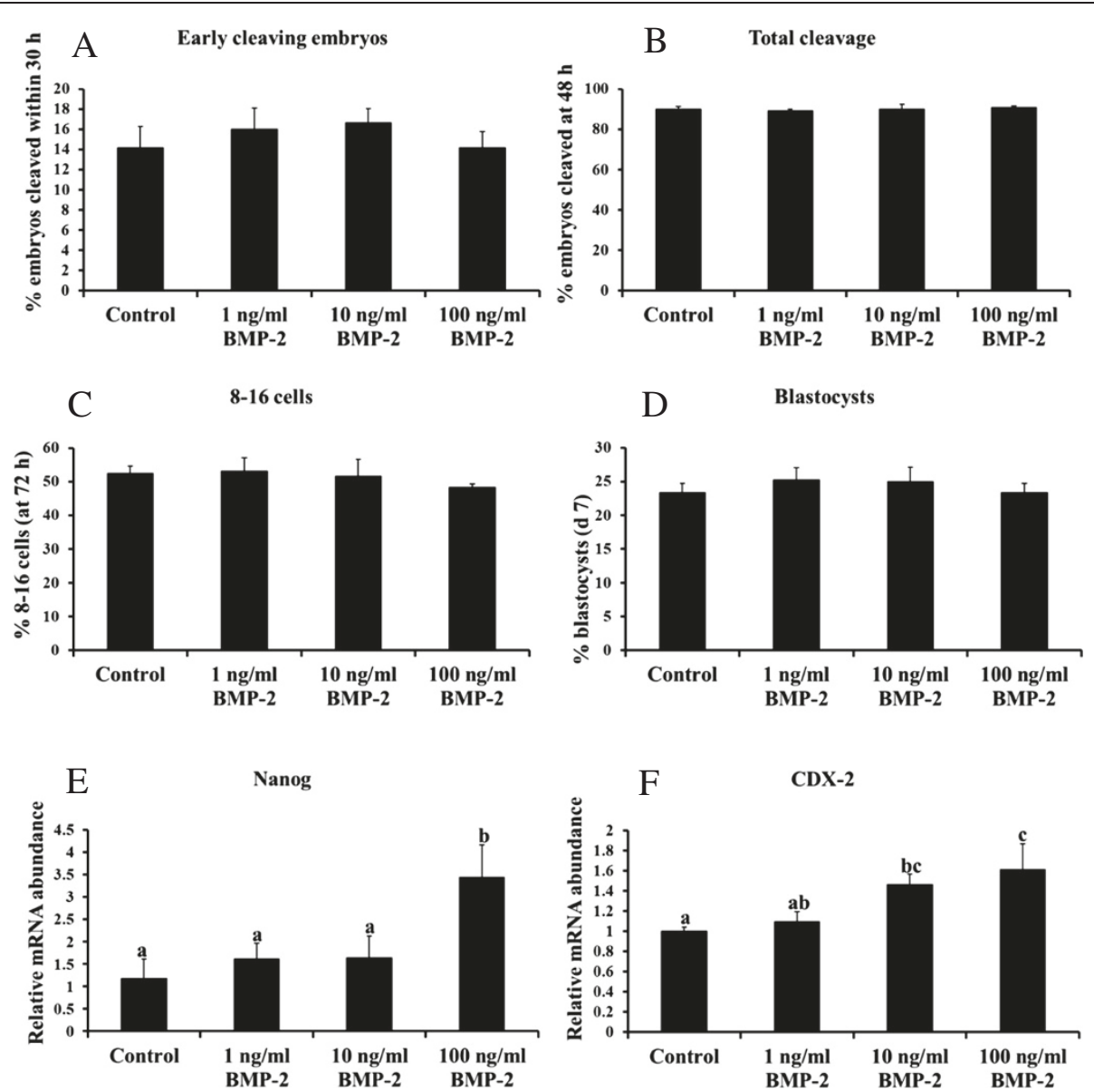

Figure 4 BMP2 regulation of bovine early embryonic development. Effects of exogenous BMP2 treatment $(0,1,10,100 \mathrm{ng} / \mathrm{ml}) \mathrm{during}$ first $72 \mathrm{~h}$ of in vitro embryo culture. ( $\mathrm{n}=30 \mathrm{embryos} / \mathrm{treatment} \mathrm{n}=4$ replicates) on proportion of early cleaving embryos that reached the two-cell stage within 30 hours post insemination (hpi) (A), total cleavage rate (determined $48 \mathrm{hpi}$ (B), rates of development to 8- to 16-cell stage (determined 72 hpi) (C) d7 blastocyst rates (D) and blastocyst mRNA abundance for NANOG (E) and CDX2 (F). Data are shown as mean \pm SEM. Values with different superscripts across treatments indicate significant differences $(P<0.05)$.

in human ES cells and signaling for both BMP2 and BMP4 is mediated via SMAD1/5 [16]. However, SMAD2/ 3 pathways are linked to $N A N O G$ promoter regulation in embryonic stem cells and antagonistic to BMP signaling and differentiation to TE fate [26]. While the addition of BMP2 had no effect on the proportion of embryos that cleaved early or developed to the $16 \mathrm{C}$ or blastocyst stages, the highest dose of BMP2 did increase both NANOG and $C D X 2$ mRNA compared to control embryos at the blastocysts stage. NANOG is a marker of the ICM of the blastocysts and is important for maintaining pluripotency of the cells in the ICM [27]. In contrast CDX2 is a marker for TE cells and is in fact required for the establishment of the TE in the blastocysts of mice and cattle $[28,29]$. NANOG and CDX2 also cross regulate each other to promote proper blastocyst formation [30]. As BMP2 supplementation increases mRNA for both markers it is possible that BMP2 enhances the differentiation of the two cell types, rather than promoting one cell type over the other.

\section{Conclusions}

In summary, results of present studies demonstrate pronounced temporal regulation of mRNA for select BMP ligands, type I and II receptors and cognate intracellular signaling molecules during bovine early embryonic development. This study was limited in that it only examined changes in abundance rather than accompanying changes in protein abundance. However, to our knowledge, temporal changes in abundance of mRNA for specific BMP including $B M P 2, B M P 3, B M P 7$ and $B M P 10$ at specific stages of bovine early embryonic development have not been examined previously. While stimulatory effects of BMP2 on early cleavage and development to $8 \mathrm{C}$ to $16 \mathrm{C}$ and blastocyst stages were not noted in response to BMP2 supplementation of culture media (at doses tested) during first $72 \mathrm{~h}$ of development, increased mRNA for CDX2 and NANOG was detected in resulting blastocysts, demonstrating a functional BMP2 signaling system in early bovine embryos. Furthermore, distinct 
results observed in present studies suggest that embryotrophic actions of follistatin reported in previous studies [3] likely are not linked to inhibition of endogenous BMP2 activity.

\section{Additional file}

Additional file 1: Figure S1. Temporal changes in RPS18 mRNA during oocyte maturation and early embryogenesis in vitro. Quantitative real time RT-PCR analysis was performed on samples of germinal vesicle (GV) and metaphase II (MII) stage oocytes and in vitro derived embryos collected at the pronuclear (PN), 2-cell (2C), 4-cell (4C), 8-cell (8C), 16-cell (16C), morula (MO) and blastocyst (BL) stages ( $n=4$ pools of 10 oocytes/ embryos per pool). Data are shown as mean \pm SEM. Values with different superscripts across time points denote significant differences $(P<0.05)$.

\section{Competing interests}

The authors declare that they have no competing interests.

\section{Authors' contributions}

KBL collected samples, isolated RNA, performed RT-qPCR analysis, performed embryo culture experiments and contributed to design of studies and interpretation of results. JKF analyzed data and contributed to design of studies, interpretation of results and helped draft the manuscript. SR performed RTqPCR analysis and contributed to design of studies and interpretation of results. GWS conceived the study, contributed to design of experiments and interpretation of results and helped draft the manuscript. All authors read and approved the final manuscript.

\section{Acknowledgements}

This project was supported by the National Institute of Child Health and Human Development of the National Institutes of Health under award number R01HD072972.

\section{Author details}

${ }^{1}$ Department of Laboratory of Mammalian Reproductive Biology and Genomics, Michigan State University, East Lansing, Ml 48824, USA. Department of Animal Science, Michigan State University, East Lansing, Ml 48824, USA. ${ }^{3}$ Department of Physiology, Michigan State University, East

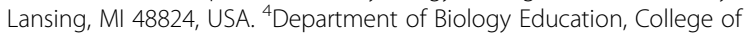
Education, Chonnam National University, Gwangju 500-757, Republic of Korea.

Received: 25 February 2014 Accepted: 7 July 2014

Published: 15 July 2014

\section{References}

1. Sirard MA, Richard F, Blondin P, Robert C: Contribution of the oocyte to embryo quality. Theriogenology 2006, 65:126-136.

2. Patel OV, Bettegowda A, Ireland JJ, Coussens PM, Lonergan P, Smith GW: Functional genomics studies of oocyte competence: evidence that reduced transcript abundance for follistatin is associated with poor developmental competence of bovine oocytes. Reproduction 2007, 133:95-106

3. Lee KB, Bettegowda A, Wee G, Ireland JJ, Smith GW: Molecular determinants of oocyte competence: potential functional role for maternal (oocyte-derived) follistatin in promoting bovine early embryogenesis. Endocrinology 2009, 150:2463-2471.

4. VandeVoort CA, Mtango NR, Lee YS, Smith GW, Latham KE: Differential effects of follistatin on nonhuman primate oocyte maturation and pre-implantation embryo development in vitro. Biol Reprod 2009, 81:1139-1146.

5. Nakamura T, Takio K, Eto Y, Shibai H, Titani K, Sugino H: Activin-binding protein from rat ovary is follistatin. Science 1990, 247:836-838.

6. Balemans W, Van Hul W: Extracellular regulation of BMP signaling in vertebrates: a cocktail of modulators. Dev Biol 2002, 250:231-250.

7. Lin SY, Morrison JR, Phillips DJ, de Kretser DM: Regulation of ovarian function by the TGF-beta superfamily and follistatin. Reproduction 2003, 126:133-148.
8. Otsuka F, Moore RK, lemura S, Ueno N, Shimasaki S: Follistatin inhibits the function of the oocyte-derived factor BMP-15. Biochem Biophys Res Commun 2001, 289:961-966

9. Kimelman D, Pyati UJ: Bmp signaling: turning a half into a whole. Cell 2005, 123:982-984.

10. Giakoumopoulos M, Golos TG: Embryonic stem cell-derived trophoblast differentiation: a comparative review of the biology, function, and signaling mechanisms. J Endocrinol 2013, 216:R33-R45.

11. Bettegowda A, Patel OV, Ireland JJ, Smith GW: Quantitative analysis of messenger RNA abundance for ribosomal protein L-15, cyclophilin-A, phosphoglycerokinase, beta-glucuronidase, glyceraldehyde 3-phosphate dehydrogenase, beta-actin, and histone $\mathrm{H} 2 \mathrm{~A}$ during bovine oocyte maturation and early embryogenesis in vitro. Mol Reprod Dev 2006, 73:267-278.

12. Livak KJ, Schmittgen TD: Analysis of relative gene expression data using real-time quantitative PCR and the 2(-Delta Delta C(T)) Method. Methods 2001, 25:402-408.

13. Kocabas AM, Crosby J, Ross PJ, Otu HH, Beyhan Z, Can H, Tam WL, Rosa GJ Halgren RG, Lim B, Fernandez E, Cibelli JB: The transcriptome of human oocytes. Proc Natl Acad Sci U S A 2006, 103:14027-14032.

14. Hussein TS, Sutton-McDowall ML, Gilchrist RB, Thompson JG: Temporal effects of exogenous oocyte-secreted factors on bovine oocyte developmental competence during IVM. Reprod Fertil Dev 2011, 23:576-584.

15. Hussein TS, Thompson JG, Gilchrist RB: Oocyte-secreted factors enhance oocyte developmental competence. Dev Biol 2006, 296:514-521.

16. Cao $X$, Chen D: The BMP signaling and in vivo bone formation. Gene 2005, 357:1-8.

17. Glister C, Kemp CF, Knight PG: Bone morphogenetic protein (BMP) ligands and receptors in bovine ovarian follicle cells: actions of BMP-4, -6 and -7 on granulosa cells and differential modulation of Smad-1 phosphorylation by follistatin. Reproduction 2004, 127:239-254.

18. Glister C, Satchell L, Knight PG: Changes in expression of bone morphogenetic proteins (BMPs), their receptors and inhibin co-receptor betaglycan during bovine antral follicle development: inhibin can antagonize the suppressive effect of BMPs on thecal androgen production. Reproduction 2010, 140:699-712.

19. Fatehi AN, van den Hurk R, Colenbrander B, Daemen AJ, van Tol HT, Monteiro RM, Roelen BA, Bevers MM: Expression of bone morphogenetic protein2 (BMP2), BMP4 and BMP receptors in the bovine ovary but absence of effects of BMP2 and BMP4 during IVM on bovine oocyte nuclear maturation and subsequent embryo development. Theriogenology 2005, 63:872-889.

20. Bettegowda A, Smith GW: Mechanisms of maternal mRNA regulation: implications for mammalian early embryonic development. Front Biosci 2007, 12:3713-3726.

21. Bettegowda A, Lee KB, Smith GW: Cytoplasmic and nuclear determinants of the maternal-to-embryonic transition. Reprod Fertil Dev 2008, 20:45-53.

22. Guhaniyogi J, Brewer G: Regulation of mRNA stability in mammalian cells. Gene 2001, 265:11-23.

23. Lee KB, Wee G, Zhang K, Folger JK, Knott JG, Smith GW: Functional Role of the Bovine Oocyte-Specific Protein JY-1 in Meiotic Maturation, Cumulus Expansion, and Subsequent Embryonic Development. Biol Reprod 2014, 90(3):Article 69 (1-7).

24. Barros R, Pereira B, Duluc I, Azevedo M, Mendes N, Camilo V, Jacobs RJ, Paulo P, Santos-Silva F, van Seuningen I, van den Brink GR, David L, Freund $J N$, Almeida R: Key elements of the BMP/SMAD pathway co-localize with CDX2 in intestinal metaplasia and regulate CDX2 expression in human gastric cell lines. J Pathol 2008, 215:411-420.

25. Hayashi Y, Furue MK, Tanaka S, Hirose M, Wakisaka N, Danno H, Ohnuma K, Oeda S, Aihara Y, Shiota K, Ogura A, Ishiura S, Asashima M: BMP4 induction of trophoblast from mouse embryonic stem cells in defined culture conditions on laminin. In Vitro Cell Dev Biol Anim 2010, 46:416-430.

26. Wu Z, Zhang W, Chen G, Cheng L, Liao J, Jia N, Gao Y, Dai H, Yuan J, Xiao L: Combinatorial signals of activin/nodal and bone morphogenic protein regulate the early lineage segregation of human embryonic stem cells. J Biol Chem 2008, 283:24991-25002.

27. Silva J, Nichols J, Theunissen TW, Guo G, van Oosten AL, Barrandon O, Wray J, Yamanaka S, Chambers I, Smith A: Nanog is the gateway to the pluripotent ground state. Cell 2009, 138:722-737.

28. Berg DK, Smith CS, Pearton DJ, Wells DN, Broadhurst R, Donnison M, Pfeffer PL: Trophectoderm lineage determination in cattle. Dev Cell 2011, 20:244-255 
29. Deb K, Sivaguru M, Yong HY, Roberts RM: Cdx2 gene expression and trophectoderm lineage specification in mouse embryos. Science 2006 311:992-996.

30. Chen L, Yabuuchi A, Eminli S, Takeuchi A, Lu CW, Hochedlinger K, Daley GQ: Cross-regulation of the Nanog and Cdx2 promoters. Cell Res 2009, 19:1052-1061.

doi:10.1186/1477-7827-12-67

Cite this article as: Lee et al: Temporal regulation of mRNAs for select bone morphogenetic proteins (BMP), BMP receptors and their associated SMAD proteins during bovine early embryonic development: effects of exogenous BMP2 on embryo developmental progression. Reproductive Biology and Endocrinology 2014 12:67.

Submit your next manuscript to BioMed Central and take full advantage of:

- Convenient online submission

- Thorough peer review

- No space constraints or color figure charges

- Immediate publication on acceptance

- Inclusion in PubMed, CAS, Scopus and Google Scholar

- Research which is freely available for redistribution

Submit your manuscript at www.biomedcentral.com/submit
C Biomed Central 